\title{
The Rationale for Growth Hormone Therapy in Children with Short Stature
}

\author{
Annalisa Deodati ${ }^{1}$, Stefano Cianfarani ${ }^{1,2}$ \\ ${ }^{1}$ University of Rome Tor Vergata, Bambino Gesù Children's Hospital, Dipartimento di Pediatria Universitario Ospedaliero, Rome, Italy \\ ${ }^{2}$ Karolinska Institutet, Department of Women's and Children's Health, Stockholm, Sweden
}

\begin{abstract}
Growth hormone $(\mathrm{GH})$ was first isolated from cadaver pituitary glands, requiring laborious and expensive collection of glands, followed by extraction and purification of the hormone. This limited supply restricted its use to children with severe GH deficiency who were treated with low dosages and suboptimal schedules. The development of recombinant DNA-derived GH, allowed the production of virtually unlimited amounts of GH, leading to the approval for therapy for a large number of childhood conditions characterized by non$\mathrm{GH}$ deficient short stature. The aim of this review is to provide a critical overview on the daily use of GH in two paradigmatic conditions of non-GH deficient short stature which are children born small for gestational age and with idiopathic short stature, highlighting the available strength of evidence for efficacy and safety.
\end{abstract}

Keywords: Growth hormone treatment, idiopathic short stature, small for gestational age

\section{Introduction}

Short stature is the most common cause of referral to pediatric endocrinology units, though the vast majority of short children have variants of growth such as constitutional delay of growth and puberty (CDGP) and familial short stature (FSS) $(1,2,3,4)$.

Due to the shortage of human growth hormone $(\mathrm{GH})$ prepared by extraction from pituitaries obtained at autopsy, for almost three decades GH therapy was limited to children with the diagnosis of GH deficiency (GHD) (5). Since 1985, when biosynthetic GH was first produced on a large-scale $(6,7,8,9,10,11,12,13)$, the virtually unlimited availability led to a rapid expansion of clinical trials to study the effect of $\mathrm{GH}$ in various conditions associated with short stature but with normal GH secretion $(14,15)$. One of the first conditions characterized by non-GH deficient short stature which was nevertheless treated with GH was Turner syndrome (TS) (16). The preliminary short-term trials, though reporting encouraging results, raised doubts about appropriateness and long-term effectiveness and safety (17). Other genetic syndromes such as Noonan syndrome (18) and achondroplasia $(19,20)$ were considered as potential indications for GH therapy. Most of these pioneering studies with biosynthetic $\mathrm{GH}$ in non-GH deficient short children were short-term trials that considered the increase in height velocity after 6-12 months of $\mathrm{GH}$ therapy as the main outcome measure for assessing GH efficacy.

Following the publication of results from long-term trials, showing efficacy and safety of GH therapy, indications for such therapy have been expanded in the last two decades. Although the most frequent condition treated with GH still remains GHD, other growth-related indications for $\mathrm{GH}$ treatment are TS, short stature homeobox-containing (SHOX) gene deficiency, Noonan syndrome, Prader-Willi syndrome, growth failure associated with chronic renal insufficiency, short stature in children born small for gestational age (SGA) who do not demonstrate catch-up growth and idiopathic short stature (ISS) (Table 1).

Therefore, the initial GH replacement therapy limited to $\mathrm{GH}$ deficient patients has metamorphosed into a pharmacological therapy to include different conditions of non-GH deficient short stature. The rationale of this treatment is based on the empiric observation of growth acceleration in response to $\mathrm{GH}$ administration, rather than on a pathophysiological 


\begin{tabular}{|c|c|}
\hline Current indications for GH therapy & $\begin{array}{l}\text { Regulatory } \\
\text { authority }\end{array}$ \\
\hline Idiopathic short stature & FDA \\
\hline \multicolumn{2}{|l|}{ Familial short stature } \\
\hline \multicolumn{2}{|l|}{ Non-familial short stature } \\
\hline \multicolumn{2}{|l|}{ Primary growth failure } \\
\hline \multicolumn{2}{|l|}{ Genetic syndromes } \\
\hline Turner syndrome & FDA/EMA \\
\hline SHOX deficit & FDA/EMA \\
\hline Noonan syndrome & FDA \\
\hline Prader-Willi syndrome & FDA/EMA \\
\hline Silver-Russell syndrome & FDA/EMA \\
\hline \multicolumn{2}{|l|}{ Other } \\
\hline Small for gestational age & FDA/EMA \\
\hline \multicolumn{2}{|l|}{ Secondary growth failure } \\
\hline Growth hormone deficiency & FDA/EMA \\
\hline \multicolumn{2}{|l|}{ Chronic systemic disease } \\
\hline Chronic renal disease & FDA/EMA \\
\hline
\end{tabular}

approach. From a biological perspective, the close relation between $\mathrm{GH}$ dose and response to therapy, in terms of growth acceleration, is well established and confirms the clinical finding of excessive height gain in children with hypersecretion of $\mathrm{GH}$-the more $\mathrm{GH}$, the more growth.

The aim of this review is to provide a critical overview on the daily use of $\mathrm{GH}$ in two paradigmatic conditions of nonGH deficient short stature, namely SGA and ISS.

\section{Small for Gestational Age}

Children born SGA are at risk of becoming short adults. Although most children born SGA show catch-up growth in the first 24 months of life, approximately $10 \%$ remain below the $3^{\text {rd }}$ centile throughout childhood and adolescence and into adulthood (21). To date, however, the mechanisms underlying postnatal catch-up growth in children born SGA are still largely unknown (22). Birth length is a more important predictor of adult height than birth weight $(22,23,24,25)$ and though genetics play a key role in controlling the growth trajectory, the endocrine mechanisms underlying early growth remain undetermined.

SGA refers to the size at birth and is defined as a birth weight and/or length of at least two standard deviation (SD) scores (SDS) below the mean for gestational age and gender $(26,27)$. The etiology of intrauterine growth retardation ultimately leading to SGA consists of a broad spectrum of maternal, environmental, placental and fetal factors, but in a significant proportion of cases the reason for being born SGA remains unclear.

SGA newborns show high circulating levels of GH and low concentrations of both insulin-like growth factor 1 (IGF1) and IGF-binding-protein-3 which normalize in the first months of postnatal life, thus suggesting a transient $\mathrm{GH}$ insensitivity $(28,29)$. In childhood and adolescence, SGA subjects show normal GH responses to stimulation tests (30). Alterations in diurnal GH secretion profile have been reported by isolated studies but are of limited diagnostic and prognostic utility $(31,32)$. On average, both IGF-1 and IGF-binding protein-3 levels are reduced in SGA children by approximately one $\mathrm{SD}$, but the individual variability is wide, indicating broad heterogeneity in the underlying endocrine and non-endocrine mechanisms.

Genetic abnormalities in the GH-IGF axis such as IGF-1 and IGF-1 receptor gene deletions and point mutations have been associated with small size at birth and severe postnatal growth retardation $(33,34,35)$.

The first short term trials with pituitary derived GH in short SGA children date back more than 50 years $(36,37)$. More recently, a promising short-term trial with biosynthetic $\mathrm{GH}$ (38) paved the way for long-term studies whose results led to the approval from regulatory authorities such as the Food and Drug Administration (FDA) in 2001 and European Medicines Agency (EMA) in 2003, although with slightly different criteria. FDA approval includes a dose of $0.48 \mathrm{mg} /$ kg per week for treatment of children born SGA who fail to manifest catch-up growth by the age of two years, whereas EMA approved GH for the treatment of short children born SGA after the age of four years at a dose of $0.22 \mathrm{mg} / \mathrm{kg}$ per week.

A consensus conference organized by the main international societies of Pediatric Endocrinology and the Growth Hormone Research Society proposed that children born SGA with height less than minus 2.5 SDS at the age of two years or with height less than minus 2 SDS at the age of four years should be eligible for $\mathrm{GH}$ treatment. The dose should range from 35 to $70 \mu \mathrm{g} / \mathrm{kg}$ per day, with the higher dose to be preferred for those with more severe growth retardation (30).

The improvement of adult height is unanimously considered the best outcome measure of the efficacy of GH therapy in SGA. The approval of this indication was based on the results from a few randomized controlled trials (RCTs) conducted until the achievement of adult height. Moreover, the available data were collected from small study cohorts treated with different treatment regimens. We set out to critically evaluate the strength of evidence by performing 
a systematic review and meta-analysis of all the available trials (39). The results of this meta-analysis showed that from an initial number of 29 studies reporting the effect of GH therapy in SGA children, only four RCTs were conducted up to the achievement of adult height, and these four studies included a total of 391 children $(40,41,42,43)$. The mean adult height of the GH-treated group exceeded controls by $0.85 \mathrm{SDS}(5.7 \mathrm{~cm})$ after eight years of therapy. Furthermore, no significant difference in efficacy was observed between the two GH dose regimens (33 vs. $67 \mu \mathrm{g} / \mathrm{kg}$ per day) (Figure 1). A wide individual variability in response to $\mathrm{GH}$ therapy was present in all studies, consistent with the heterogeneity of conditions underlying SGA. The quality grading of the studies was performed according to Endocrine Society criteria (44) and revealed that all four RCTs had moderate quality evidence.

Although there is a large body of evidence suggesting that low birth weight is associated with a high risk of developing insulin resistance, glucose intolerance and metabolic disorders in later life, thus far $\mathrm{GH}$ treatment in SGA children has not been associated with major side effects. A transient insulin resistance, increased fasting glucose and reduced tolerance during oral glucose-tolerance testing have been reported $(42,43,45,46)$. Longer follow-up of SGA subjects treated with GH during childhood, up to six years after discontinuation of therapy, showed a similar body composition, insulin sensitivity, blood pressure and a more beneficial lipid profile compared with untreated, short, young adults born SGA $(47,48,49)$.

$\mathrm{GH}$ treatment has been reported not to influence the age at onset and progression of puberty, regardless of the dose (50) and duration of puberty and pubertal height gain are apparently not affected by the use of higher doses of GH $(50,51,52)$. Moreover, GH therapy seems to improve body composition and cardiovascular profiles in children born SGA, reducing fat mass, blood pressure and lipid levels and increasing lean body mass $(46,53)$. Even intelligence, psychosocial functioning and quality of life (QOL) have been reported to improve during GH therapy in SGA children $(54,55,56)$.

Treated children Control children

\begin{tabular}{|c|c|c|c|c|c|c|c|c|}
\hline RCTs & Mean & $\begin{array}{l}\text { SD } \\
\text { score }\end{array}$ & Total & Mean & $\begin{array}{l}\text { SD } \\
\text { score }\end{array}$ & Total & Weight \% & Mean difference ( $95 \% \mathrm{IC})$ \\
\hline Carel et al (40) & -2.1 & 1 & 102 & -2.7 & 0.9 & 47 & $21.3 \%$ & $0.6(0.28-0.92)$ \\
\hline $\begin{array}{l}\text { Dahlgren et al (4l) } \\
<2 \text { anni }\end{array}$ & -1.6 & 0.8 & 41 & -2 & 0.8 & 34 & $20.2 \%$ & $0.40(0.04-0.76)$ \\
\hline $\begin{array}{l}\text { Dahlgren et al (41) } \\
>2 \text { anni }\end{array}$ & -1.2 & 0.7 & 36 & -2 & 0.8 & 34 & $20.5 \%$ & $0.8(0.45-1.15)$ \\
\hline van Dijket al (43) & -1.4 & 1 & 37 & -2.6 & 0.6 & 25 & $19.2 \%$ & $1.20(0.8-1.60)$ \\
\hline $\begin{array}{l}\text { Van Pareren et al } \\
\text { (42) }\end{array}$ & -1 & 0.8 & 54 & -2.3 & 0.7 & 15 & $18.8 \%$ & $1.30(0.89-1.71)$ \\
\hline Totale $(95 \%$ IC) & & & 270 & & & 155 & $100 \%$ & $0.85(0.52-1.17)$ \\
\hline
\end{tabular}

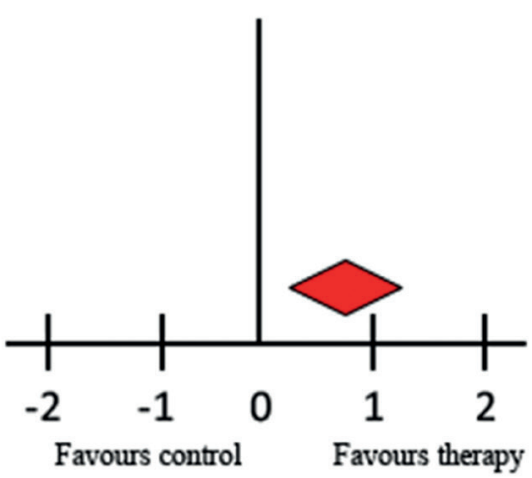

Figure 1. Effect of long term growth hormone therapy on adult height in randomised controlled trials. Results of metaanalysis according to random model (39) in children born small for gestational age. The mean difference in adult height between treated and untreated children was 0.85 standard deviation (IC 95\% 0.52-1.17, p < 0.001)

SD: standard deviation, RCTs: randomized controlled trials 
In general, GH therapy is not indicated in SGA during adolescence due to the reduced growth potential remaining after entering puberty. However, combined therapy with GH and gonadotropin releasing hormone analogs (administered for two years) has recently been reported to be safe and effective in improving adult height in SGA children with more severe growth retardation at the onset of puberty $(57,58)$.

Children with Silver-Russell syndrome (SRS) constitute a syndromic subgroup of SGA and were classically considered to be less, or even non-responsive, to GH therapy (30). Smeets et al (59) have recently reported that SRS children are significantly shorter than non-SRS SGA children at start of $\mathrm{GH}$ therapy but gain more height during treatment, resulting in a similar height SDS at onset of puberty in SRS and non-SRS. Thereafter, there is a decline in height SDS from puberty onset to adult height attainment in SRS compared to non-SRS, leading to a significantly shorter adult height (59). However, although SRS children do not attain the same adult height as non-SRS, the total height gain is similar suggesting a positive growth promoting effect of such therapy (59). In addition, a positive effect of $\mathrm{GH}$ therapy on body composition, motor development, appetite and reduced risk of hypoglycemia has been reported $(59,60)$.

Wide individual variability in response to GH therapy has been reported in all studies. Multiple linear regression analyses were used to construct the best model for predicting adult height SDS. The major predictors of adult height reported so far are: (i) height and weight at the start of GH treatment; (ii) target height; (iii) pretreatment growth rate; and (iv) prepubertal years treated with GH $(61,62)$.

Is GH therapy a panacea for children born SGA? Although the results of most studies strongly encourage GH treatment in SGA children, it has to be pointed out that (i) the longitudinal follow-up is still relatively short; (ii) the overall number of children enrolled in the trials is relatively small, but, more importantly, (iii) almost all studies have been performed by the same group of investigators in the Netherlands, thus leaving open the question about the replicability of their results in other geographical and scientific contexts.

\section{Idiopathic Short Stature}

The story of GH treatment in children with ISS begins in 1983 with the first trial conducted with pituitary derived GH in 15 non-GH deficient short children who were treated for six months (15). In all children, growth rate increased by more than $2.0 \mathrm{~cm}$ per year during treatment. This shortterm study paved the way for a series of trials which led to FDA approval for such an indication in 2003.
ISS is defined as a condition in which the height of an individual is more than 2 SDS below the corresponding mean height for a given age, sex and population, without evidence of systemic, endocrine, nutritional, or chromosomal abnormalities $(63,64)$. Therefore, children defined as having ISS have a normal size at birth and normal GH secretion. ISS is defined by criteria rather than a diagnosis per se and encompasses a variety of conditions including both mild skeletal abnormalities not falling into any of the known, classified disorders and non-syndromic genetic conditions, as well as normal variants of growth such as CDGP and FSS (65).

In 2003, GH therapy was approved in the United States for children with ISS with height at or less than -2.25 SDS (1.2 percentile) below the mean for age and sex, associated with growth rates unlikely to permit attainment of adult height in the normal range, and in whom diagnostic work up excluded other causes for short stature that should be observed or treated by other means. A consensus conference of the International Societies of Pediatric Endocrinology and the Growth Hormone Research Society proposed that children with ISS whose heights are less than -2.0 SDS and who are more than 2.0 SDS below their mid-parental target height or had a predicted height less than -2.0 SDS warrant consideration for treatment (63).

However, controversy still exists about the degree of effectiveness of GH therapy in children with ISS (66). A preliminary systematic review of literature showed that one year of GH therapy induced an acceleration of growth velocity and suggested that long-term GH therapy was able to increase adult height (67). However, this systematic review did not consider the outcome measures analytically and did not evaluate and classify the trials according to the quality of evidence and strength of recommendation. Furthermore, at that time, the review could take into account the results of only one randomized control trial, limited to eight girls followed up to the achievement of adult height (68). The authors, cautiously and wisely concluded that the focus of assessment should increasingly shift from efficacy in promoting growth to effectiveness in promoting health and well-being as a function of increased growth (67).

A more detailed and updated meta-analysis of available trials, including quality grading according to the Endocrine Society criteria which classifies the quality of evidence into one of four categories (high, moderate, low and very low) (44) was performed by the authors of this review in 2011 (69). The aim was to systematically determine the impact of GH therapy on adult height of children with ISS. This systematic review of the literature showed that from an initial number of 19 long-term trials, only ten met 
the criteria of controlled trials. Three RCTs (including 115 children, 79 cases and 36 controls) $(68,70,71)$ and seven non-RCTs (including 477 children, 181 cases and 296 controls) $(72,73,74,75,76,77,78)$ reported data on adult height. Two randomized clinical trials were classed as of moderate quality evidence and one of low quality evidence. Six non-randomized clinical trials were classed as of low quality evidence and one of low-moderate quality evidence. The adult height of the $\mathrm{GH}$ treated children exceeded, on average, that of the controls by $0.65 \mathrm{SD}$ (about $4 \mathrm{~cm}$ ) (Figure 2). In the seven non-RCTs, the adult height of the GH treated group exceeded, on average, that of the controls by 0.45 SDS (about $3 \mathrm{~cm}$ ).

The main conclusions were that: (i) no single, high quality evidence, RCT was carried out up to the achievement of adult height; (ii) that the overall magnitude of GH effect in reducing the adult height deficit in children with ISS was on average less than that achieved in other conditions for which GH was licensed and; (iii) that the individual response to therapy was highly variable (69).
More recently, van Gool et al (79) have reported that high dose GH therapy in prepubertal children with ISS does not improve adult height, as it increases height gain during treatment but, at the same time, accelerates bone maturation, resulting in a similar adult height compared with the untreated controls.

Finally, the effect on adult height of a combined therapy with GH plus gonadotropin-releasing hormone analogs in ISS adolescents with relatively early puberty was assessed. The modest results in height gain led the authors to advise physicians against the use of this treatment in clinical practice (80).

Because estrogens mediate skeletal maturation and epiphyseal fusion, aromatase inhibitors have been used to delay bone maturation. The first trial with aromatase inhibitors was performed in boys with CDPG with apparently promising results $(81,82)$ and, afterwards in children with ISS alone (83) or in combination with GH $(84,85)$. These still preliminary results indicate that aromatase inhibitors, especially in combination with $\mathrm{GH}$, seem to be effective

Treated children Control children

\begin{tabular}{|c|c|c|c|c|c|c|c|c|}
\hline RCTs & Mean & $\begin{array}{c}\text { SD } \\
\text { score }\end{array}$ & Total & Mean & $\begin{array}{c}\text { SD } \\
\text { score }\end{array}$ & Total & Weight $\%$ & Mean difference ( $95 \%$ IC) \\
\hline $\begin{array}{l}\text { Albertsson-Wikland et al (71) } \\
0.033 \mathrm{mg} / \mathrm{kg} / \text { day dose }\end{array}$ & -1.70 & 0.68 & 18 & -2.20 & 0.75 & 19 & 30.0 & $0.50(0.04-0.96)$ \\
\hline $\begin{array}{l}\text { Albertsson-Wikland et al (71) } \\
0.067 \mathrm{mg} / \mathrm{kg} / \text { day dose }\end{array}$ & -1.50 & 0.84 & 31 & -2.20 & 0.75 & 19 & 31.7 & $0.70(0.25-1.15)$ \\
\hline Leschek et al (70) & -1.77 & 0.80 & 22 & -2.34 & 0.56 & 11 & 28.8 & $0.57(0.10-1.04)$ \\
\hline McCaughey et al (68) & -1.14 & 1.06 & 8 & -2.37 & 0.46 & 6 & 9.4 & $1.23(0.41-2.05)$ \\
\hline Totale (95\% IC) & & & 79 & & & 55 & 100.0 & $0.65(0.40-0.91)$ \\
\hline
\end{tabular}

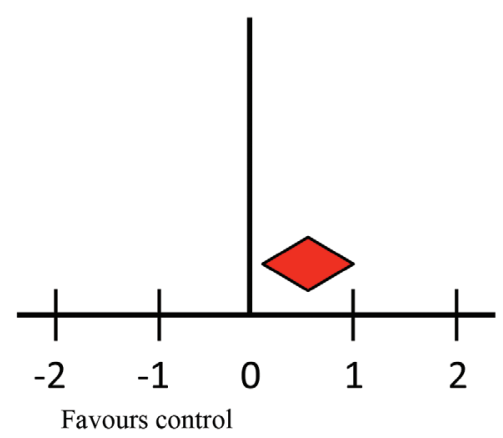

Figure 2. Effect of long term growth hormone therapy on adult height in randomised controlled trials. Results of metaanalysis according to random model (69) in children with idiopathic short stature (ISS). The mean difference in adult height between treated and untreated ISS children was 0.65 standard deviation (IC 95\% 0.4-0.91, p $<0.001$ )

SD: standard deviation, RCT: randomized controlled trial 
in stimulating growth. However, caution is needed as potential adverse effects include reduced high-density lipoprotein cholesterol, increased insulin resistance, vertebral deformities, impairment of cognitive function and long-term effects on spermatogenesis and infertility (86). Therefore, the use of aromatase inhibitors must be considered experimental and to be performed only in strictly controlled clinical trials.

Wide individual variability in the response to GH therapy was reported in all clinical trials conducted in ISS children. The major predictors of adult height reported so far were: (i) early age at start of therapy; (ii) dose of GH; (iii) length at birth; (iv) difference between height and mid-parental height and; (v) delay in bone age (87).

In conclusion, the available evidence suggests that longterm GH therapy reduces the adult height deficit in children with ISS. The still open question is whether this treatment is worthwhile considering the impact of the height gained on physical and psychosocial wellbeing, burden for patients and parents, potential adverse effects, cost of therapy and patients'/parents' expectations.

\section{Final Remarks}

The available evidence shows that GH therapy can increase adult height in non-GH deficient short children born SGA or with ISS. However, in both conditions the efficacy is far less than in GHD. A critical review of available data shows that to date, no study has fulfilled the evidence based medicine criteria for high quality of evidence and strong recommendation. The individual response to therapy is highly variable and further studies are needed to identify what defines the responders.

The assumption underlying the pharmacological use of $\mathrm{GH}$ in non-GH deficient short children is that GH treatment, by increasing adult height, improves the QOL of subjects with short stature. However, data are conflicting and inconclusive, and this potential effect cannot be considered at the moment as a strong argument for such therapy (55, $88,89,90,91,92,93,94,95,96)$.

The long-term safety of $\mathrm{GH}$ therapy has recently been questioned by observational studies reporting increased risk of mortality and morbidity in young adults treated with GH during childhood $(97,98)$. Although these data have not been confirmed $(99,100,101)$, continued surveillance of subjects exposed to recombinant human $\mathrm{GH}$ is essential both during treatment and in the years after treatment cessation $(102,103)$.

Finally, further high-quality evidence from randomised, double blind, placebo controlled trials up to the achievement of adult height would be necessary to determine the real efficacy, ideal dosage and long term safety of GH therapy in non-GH deficient short children.

\section{Ethics}

Peer-review: Internally peer-reviewed.

\section{Authorship Contributions}

Concept: Stefano Cianfarani, Annalisa Deodati, Design: Stefano Cianfarani, Annalisa Deodati, Analysis or Interpretation: Stefano Cianfarani, Annalisa Deodati, Literature Search: Stefano Cianfarani, Annalisa Deodati, Writing: Stefano Cianfarani, Annalisa Deodati.

Financial Disclosure: The authors declared that this study received no financial support.

\section{References}

1. Pedicelli S, Peschiaroli E, Violi E, Cianfarani S. Controversies in the definition and treatment of idiopathic short stature (ISS). J Clin Res Pediatr Endocrinol 2009;1:105-115. Epub 2009 Feb 1

2. Cohen P, Rogol AD, Deal CL, Saenger P, Reiter EO, Ross JL, Chernausek $\mathrm{SD}$, Savage MO, Wit JM. Consensus statement on the diagnosis and treatment of children with idiopathic short stature: a summary of the Growth Hormone Research Society, the Lawson Wilkins Pediatric Endocrine Society, and the European Society for Paediatric Endocrinology Workshop. J Clin Endocrinol Metab 2008;93:42104217. Epub 2008 Sep 9

3. Stanhope R, Preece MA. Management of constitutional delay of growth and puberty. Arch Dis Child 1988;63:1104-1110.

4. Albanese A, Stanhope R. Predictive factors in the determination of final height in boys with constitutional delay of growth and puberty. J Pediatr 1995; 126:545-550.

5. Raben MS. Treatment of a pituitary dwarf with human growth hormone. J Clin Endocrinol Metab 1958;18:901-903.

6. Ranke MB. Clinical experience with authentic recombinant human growth hormone. Acta Paediatr Scand Suppl 1986;325:90-92.

7. Wilton P, Sietnieks A. An open-labelled study of the safety, acute metabolic activity and pharmacokinetic profile of a short-term course of recombinant human growth hormone in healthy volunteers. Clin Endocrinol (Oxf) 1987;26:125-128.

8. Fryklund LM, Bierich JR, Ranke MB. Recombinant human growth hormone. Clin Endocrinol Metab 1986;15:511-535

9. Takano K, Shizume K, Hibi I, Okuno A, Hanyu K, Suwa S, Nakajima H, Kondo T, Kato K, Iwatani N, Momoi T, Chihara K, Shirakawa E, Kohno $\mathrm{H}$. Treatment of pituitary dwarfism with authentic recombinant human growth hormone (SM-9500). Endocrinol Jpn 1987;34:291-297.

10. Martial JA, Hallewell RA, Baxter JD, Goodman HM. Human growth hormone: complementary DNA cloning and expression in bacteria. Science 1979;205:602-607

11. Goeddel DV, Heyneker HL, Hozumi T, Arentzen R, Itakura K, Yansura DG, Ross MJ, Miozzari G, Crea R, Seeburg PH. Direct expression in Escherichia coli of a DNA sequence coding for human growth hormone. Nature 1979;281:544-548.

12. Olson KC, Fenno J, Lin N, Harkins RN, Snider C, Kohr WH, Ross MJ, Fodge D, Prender G, Stebbing N. Purified human growth hormone from E. coli is biologically active. Nature 1981;293:408-411. 
13. Hintz RL, Rosenfeld RG, Wilson DM, Bennett A, Finno J, McClellan B, Swift R. Biosynthetic methionyl human growth hormones is biologically active in adult man. Lancet 1982;5:1276-1279.

14. Ranke MB. Human growth hormone therapy of non-growth hormone deficient children. Pediatrician 1987;14:178-182.

15. Van Vliet G, Styne DM, Kaplan SL, Grumbach MM. Growth hormone treatment for short stature. N Engl J Med 1983;309:1016-1022.

16. Raiti S, Moore WV, Van Vliet G, Kaplan SL. Growth-stimulating effects of human growth hormone therapy in patients with Turner syndrome. J Pediatr 1986;109:944-949.

17. Cianfarani S, Vaccaro F, Boscherini B. What is the rationale for growth hormone therapy in Turner's syndrome? Lancet 1994;344:114-115.

18. Cianfarani S, Spadoni GL, Finocchi G, Ravet P, Costa F, Papa M, Scirè G, Manca Bitti ML, Boscherini B. [Treatment with growth hormone (GH) in 3 cases of Noonan syndrome]. Minerva Pediatr 1987;39:281-284.

19. Horton WA, Hecht JT, Hood OJ, Marshall RN, Moore WV, Hollowell JG. owth hormone therapy in achondroplasia. Am J Med Genet 1992;42:667-670.

20. Nishi 1, Kajiyama M, Miyagawa S, Fujiwara M, Hamamoto K. Growth hormone therapy in achondroplasia. Acta Endocrinol (Copenh) 1993;128:394-396.

21. Karlberg J, Albertsson-Wikland K. Growth in full-term small-forgestational-age infants: from birth to final height. Pediatr Res 1995;38:733-739.

22. Cianfarani S, Ladaki C, Geremia C. Hormonal regulation of postnatal growth in children born small for gestational age. Horm Res 2006;65 Suppl 3:70-74. Epub 2006 Apr 10

23. Hokken-Koelega AC, De Ridder MA, Lemmen RJ, Den Hartog H, De Muinck Keizer-Schrama SM, Drop SL.Children born small for gestational age: do they catch up? Pediatr Res 1995;38:267-271.

24. Leger J, Limoni C, Collin D, Czernichow P. Prediction factors in the determination of final height in subjects born small for gestational age. Pediatr Res 1998;43:808-812.

25. Luo ZC, Albertsson-Wikland K, Karlberg J. Length and body mass index at birth and target height influences on patterns of postnatal growth in children born small for gestational age. Pediatrics 1998;102:E72.

26. Lee PA, Chernausek SD, Hokken-Koelega AC, Czernichow P; International Small for Gestational Age Advisory Board. International Small for Gestational Age Advisory Board consensus development conference statement: management of short children born small for gestational age, April 24-October 1, 2001. Pediatrics 2003;111:12531261 .

27. Clayton PE, Cianfarani S, Czernichow P, Johannsson G, Rapaport R, Rogol A. Management of the child born small for gestational age through to adulthood: a consensus statement of the International Societies of Pediatric Endocrinology and the Growth Hormone Research Society. J Clin Endocrinol Metab 2007;9:804-810. Epub 2007 Jan 2

28. Leger J, Noel M, Limal JM, Czernichow P. Growth factors and intrauterine growth retardation. II. Serum growth hormone, insulinlike growth factor (IGF) I, and IGF-binding protein 3 levels in children with intrauterine growth retardation compared with normal control subjects: prospective study from birth to two years of age. Study Group of IUGR. Pediatr Res 1996;40:101-107.

29. Cianfarani S, Germani D, Rossi P, Rossi L, Germani A, Ossicini C, Zuppa A, Argirò G, Holly JM, Branca F. Intrauterine growth retardation: evidence for the activation of the insulin-like growth factor (IGF)related growth-promoting machinery and the presence of a cationindependent IGF binding protein-3 proteolytic activity by two months of life. Pediatr Res 1998;44:374-380.
30. Clayton PE, Cianfarani S, Czernichow P, Johannsson G, Rapaport R, Rogol A. Management of the child born small for gestational age through to adulthood: a consensus statement of the International Societies of Pediatric Endocrinology and the Growth Hormone Research Society. J Clin Endocrinol Metab 2007;92:804-810. Epub 2007 Jan 2

31. de Waal WJ, Hokken-Koelega AC, Stijnen T, de Muinck Keizer-Schrama SM, Drop SL. Endogenous and stimulated GH secretion, urinary GH excretion, and plasma IGF-I and IGF-II levels in prepubertal children with short stature after intrauterine growth retardation. The Dutch Working Group on Growth Hormone. Clin Endocrinol (Oxf) 1994;41:621-630.

32. Boguszewski M, Rosberg S, Albertsson-Wikland K. Spontaneous 24hour growth hormone profiles in prepubertal small for gestational age children. J Clin Endocrinol Metab 1995;80:2599-2606.

33. Woods KA, Camacho-Hübner C, Savage MO, Clark AJ. Intrauterine growth retardation and postnatal growth failure associated with deletion of the insulin-like growth factor I gene. N Engl J Med 1996;335:13631367.

34. Abuzzahab MJ, Schneider A, Goddard A, Grigorescu F, Lautier C, Keller E, Kiess W, Klammt J, Kratzsch J, Osgood D, Pfäffle R, Raile K, Seidel B, Smith RJ, Chernausek SD; Intrauterine Growth Retardation (IUGR) Study Group. IGF-I receptor mutations resulting in intrauterine and postnatal growth retardation. N Engl J Med 2003;349:2211-2222.

35. Wit JM, Oostdijk W, Losekoot M, van Duyvenvoorde HA, Ruivenkamp CA, Kant SG. MECHANISMS IN ENDOCRINOLOGY: Novel genetic causes of short stature. Eur J Endocrinol 2016;174:R145-173. Epub 2015 Nov 17

36. Tanner JM, Ham TJ. Low birthweight dwarfism with asymmetry (Silver's syndrome): treatment with human growth hormone. Arch Dis Child 1969;44:231-243.

37. Lee PA, Blizzard RM, Cheek DB, Holt AB. Growth and body composition in intrauterine growth retardation (IUGR) before and during human growth hormone administration. Metabolism 1974;23:913-919.

38. de Zegher F, Albertsson-Wikland K, Wollmann HA, Chatelain P, Chaussain JL, Löfström A, Jonsson B, Rosenfeld RG. Growth hormone treatment of short children born small for gestational age: growth responses with continuous and discontinuous regimens over 6 years. J Clin Endocrinol Metab 2000;85:2816-2821.

39. Maiorana A, Cianfarani S. Impact of growth hormone therapy on adult height of children born small for gestational age. Pediatrics 2009;124:e519-531. Epub 2009 Aug 10

40. Carel JC, Chatelain P, Rochiccioli P, Chaussain JL. Improvement in adult height after growth hormone treatment in adolescents with short stature born small for gestational age: results of a randomized controlled study. J Clin Endocrinol Metab 2003;88:1587-1593.

41. Dahlgren J, Wikland KA; Swedish Study Group for Growth Hormone Treatment. Final height in short children born small for gestational age treated with growth hormone. Pediatr Res 2005;57:216-222. Epub $2004 \operatorname{Dec} 7$

42. Van Pareren Y, Mulder P, Houdijk M, Jansen M, Reeser M, HokkenKoelega A. Adult height after long-term, continuous growth hormone $(\mathrm{GH})$ treatment in short children born small for gestational age: results of a randomized, double-blind, dose-response GH trial. J Clin Endocrinol Metab 2003;88:3584-3590.

43. van Dijk M, Bannink EM, van Pareren YK, Mulder PG, Hokken-Koelega AC. Risk factors for diabetes mellitus type 2 and metabolic syndrome are comparable for previously growth hormone-treated young adults born small for gestational age (sga) and untreated short SGA controls. J Clin Endocrinol Metab 2007;92:160-165. Epub 2006 Oct 24

44. Swiglo BA, Murad MH, Schünemann HJ, Kunz R, Vigersky RA, Guyatt GH, Montori VM. A case for clarity, consistency, and helpfulness: state-of-the-art clinical practice guidelines in endocrinology using 
the grading of recommendations, assessment, development, and evaluation system. J Clin Endocrinol Metab 2008;93:666-673. Epub 2008 Jan 2

45. Sas T, de Waal W, Mulder P, Houdijk M, Jansen M, Reeser M, HokkenKoelega A. Growth hormone treatment in children with short stature born small for gestational age: 5-year results of a randomized, doubleblind, dose-response trial. J Clin Endocrinol Metab 1999;84:30643070.

46. Sas T, Mulder P, Hokken-Koelega A. Body composition, blood pressure, and lipid metabolism before and during long-term growth hormone $(\mathrm{GH})$ treatment in children with short stature born small for gestational age either with or without GH deficiency. J Clin Endocrinol Metab 2000;85:3786-3792.

47. Breukhoven PE, Kerkhof GF, van Dijk M, Hokken-Koelega AC. Longterm impact of $\mathrm{GH}$ treatment during childhood on body composition and fat distribution in young adults born SGA. J Clin Endocrinol Metab 2011;96:3710-3716

48. van der Steen M, Smeets CC, Kerkhof GF, Hokken-Koelega AC. Metabolic health of young adults who were born small for gestational age and treated with growth hormone, after cessation of growth hormone treatment: a 5-year longitudinal study. Lancet Diabetes Endocrino 2017;5:106-116. Epub 2016 Dec 21

49. Swerdlow AJ, Cooke R, Beckers D, Borgström B, Butler G, Carel JC, Cianfarani S, Clayton P, Coste J, Deodati A, Ecosse E, Gausche R, Giacomozzi C, Hokken-Koelega ACS, Khan AJ, Kiess W, Kuehni CE, Mullis PE, Pfaffle R, Sävendahl L, Sommer G, Thomas M, Tidblad A, Tollerfield S, Van Eycken L, Zandwijken GRJ.Cancer Risks in Patients Treated With Growth Hormone in Childhood: The SAGhE European Cohort Study. J Clin Endocrinol Metab 2017;102:1661-1672.

50. Boonstra V, van Pareren Y, Mulder P, Hokken-Koelega A. HokkenKoelega. Puberty in growth hormone-treated children born small for gestational age (SGA). J Clin Endocrinol Metab 2003;88:5753-5758.

51. Boonstra VH, Mulder PG, de Jong FH, Hokken-Koelega AC. Serum dehydroepiandrosterone sulfate levels and pubarche in short children born small for gestational age before and during growth hormone treatment. J Clin Endocrinol Metab 2004;89:712-717.

52. Boonstra VH, Weber RF, de Jong FH, Hokken-Koelega AC. HokkenKoelega. Testis function in prepubertal boys and young men born small for gestational age. Horm Res 2008;70:357-363. Epub 2008 Oct 27

53. Willemsen RH, Arends NJ, Bakker-van Waarde WM, Jansen M, van Mil EG, Mulder J, Odink RJ, Reeser M, Rongen-Westerlaken C, StokvisBrantsma WH, Waelkens JJ, Hokken-Koelega AC. Long-term effects of growth hormone $(\mathrm{GH})$ treatment on body composition and bone mineral density in short children born small-for-gestational-age: sixyear follow-up of a randomized controlled GH trial. Clin Endocrinol (Oxf) 2007;67:485-492. Epub 2007 Jun 11

54. van Pareren YK, Duivenvoorden HJ, Slijper FS, Koot HM, HokkenKoelega AC. Intelligence and psychosocial functioning during longterm growth hormone therapy in children born small for gestational age. J Clin Endocrinol Metab 2004;89:5295-5302.

55. Bannink EM, van Pareren YK, Theunissen NC, Raat H, Mulder PG, Hokken-Koelega AC. Quality of life in adolescents born small for gestational age: does growth hormone make a difference? Horm Res 2005;64:166-174. Epub 2005 Oct 4

56. Bannink E, Djurhuus CB, Christensen T, Jøns K, Hokken-Koelega A. Adult height and health-related quality of life after growth hormone therapy in small for gestational age subjects. J Med Econ 2010;13:221 227.

57. Lem AJ, van der Kaay DC, de Ridder MA, Bakker-van Waarde WM, van der Hulst FJ, Mulder JC, Noordam C, Odink RJ, Oostdijk W, Schroor EJ, Sulkers EJ, Westerlaken C, Hokken-Koelega AC. Adult height in short children born SGA treated with growth hormone and gonadotropin releasing hormone analog: results of a randomized, dose-response $\mathrm{GH}$ trial. J Clin Endocrinol Metab 2012;97:4096-4105. Epub 2012 Aug 17

58. van der Steen M, Lem AJ, van der Kaay DC, Hokken-Koelega AC. Insulin Sensitivity and $\beta$-Cell Function in SGA Children Treated With GH and GnRHa: Results of a Long-Term Trial. J Clin Endocrinol Metab 2016;101:705-713. Epub 2015 Dec 14

59. Smeets CC, Zandwijken GR, Renes JS, Hokken-Koelega AC. Long-Term Results of GH Treatment in Silver-Russell Syndrome (SRS): Do They Benefit the Same as Non-SRS Short-SGA? J Clin Endocrinol Metab 2016;101:2105-2112. Epub 2016 Mar 23

60. Wakeling EL, Brioude F, Lokulo-Sodipe O, O'Connell SM, Salem J, Bliek J, Canton AP, Chrzanowska KH, Davies JH, Dias RP, Dubern B, Elbracht M, Giabicani E, Grimberg A, Grønskov K, Hokken-Koelega AC, Jorge AA, Kagami M, Linglart A, Maghnie M, Mohnike K, Monk D, Moore GE, Murray PG, Ogata T, Petit IO, Russo S, Said E, Toumba M, Tümer Z, Binder G, Eggermann T, Harbison MD, Temple IK, Mackay DJ, Netchine I. Diagnosis and management of Silver-Russell syndrome: first international consensus statement. Nat Rev Endocrinol 2017;13:105124. Epub 2016 Sep 2

61. Ranke MB, Lindberg A; KIGS International Board. Height at start, first-year growth response and cause of shortness at birth are major determinants of adult height outcomes of short children born small for gestational age and Silver-Russell syndrome treated with growth hormone: analysis of data from KIGS. Horm Res Paediatr 2010;74:259266. Epub 2010 Apr 30

62. Ranke MB, Lindberg A; KIGS International Board. Prediction models for short children born small for gestational age (SGA) covering the total growth phase. Analyses based on data from KIGS (Pfizer International Growth Database). BMC Med Inform Decis Mak 2011;11:38.

63. Cohen P, Rogol AD, Deal CL, Saenger P, Reiter EO, Ross JL, Chernausek SD, Savage MO, Wit JM; 2007 ISS Consensus Workshop participants. Consensus statement on the diagnosis and treatment of children with idiopathic short stature: a summary of the Growth Hormone Research Society, the Lawson Wilkins Pediatric Endocrine Society, and the European Society for Paediatric Endocrinology Workshop. J Clin Endocrinol Metab 2008;93:4210-4217. Epub 2008 Sep 9

64. Ranke MB. Towards a consensus on the definition of idiopathic short stature. Horm Res 1996;45(Suppl 2):64-66.

65. Wit JM, Clayton PE, Rogol AD, Savage MO, Saenger PH, Cohen P. Idiopathic short stature: definition, epidemiology, and diagnostic evaluation. Growth Horm IGF Res 2008;18:89-110. Epub 2008 Jan 7

66. Ranke MB, Lindberg A. The basis for optimising growth with growth hormone usage in children with idiopathic short stature: analysis of data from KIGS (Pfizer International Growth Study Database). Horm Res Paediatr 2011;76(Suppl 3):48-50. Epub 2011 Sep 7

67. Finkelstein BS, Imperiale TF, Speroff T, Marrero U, Radcliffe DJ, Cuttler L. Effect of growth hormone therapy on height in children with idiopathic short stature: a meta-analysis. Arch Pediatr Adolesc Med 2002;156:230-240.

68. McCaughey ES, Mulligan J, Voss LD, Betts PR. Randomised trial of growth hormone in short normal girls. Lancet 1998;351:940-944.

69. Deodati A, Cianfarani S. Impact of growth hormone therapy on adult height of children with idiopathic short stature: systematic review. BMJ 2011;342:c7157

70. Leschek EW, Rose SR, Yanovski JA, Troendle JF, Quigley CA, Chipman JJ, Crowe BJ, Ross JL, Cassorla FG, Blum WF, Cutler GB Jr, Baron J; National Institute of Child Health and Human Development-Eli Lilly $\&$ Co. Growth Hormone Collaborative Group. Effect of growth hormone treatment on adult height in peripubertal children with idiopathic short stature: a randomized, double-blind, placebo-controlled trial. J Clin Endocrinol Metab 2004;89:3140-3148, 
71. Albertsson-Wikland K, Aronson AS, Gustafsson J, Hagenäs L, Ivarsson SA, Jonsson B, Kriström B, Marcus C, Nilsson KO, Ritzén EM, Tuvemo $\mathrm{T}$, Westphal $\mathrm{O}$, Aman J. Dose-dependent effect of growth hormone on final height in children with short stature without growth hormone deficiency. J Clin Endocrinol Metab 2008;93:4342-4350. Epub 2008 Aug 26

72. Wit JM, Boersma B, de Muinck Keizer-Schrama SM, Nienhuis HE, Oostdijk W, Otten BJ, Delemarre-Van de Waal HA, Reeser M, Waelkens JJ, Rikken B, Massa GG, Dutch Growth Hormone Working Group. Long-term results of growth hormone therapy in children with short stature, subnormal growth rate and normal growth hormone response to secretagogues. Dutch Growth Hormone Working Group. Clin Endocrinol (Oxf) 1995;42:365-372.

73. Hindmarsh PC, Brook CG. Final height of short normal children treated with growth hormone. Lancet 1996;348:13-16.

74. Buchlis JG, Irizarry L, Crotzer BC, Shine BJ, Allen L, MacGillivray MH. Comparison of final heights of growth hormone-treated vs. untreated children with idiopathic growth failure. J Clin Endocrinol Metab 1998;83:1075-1079.

75. J López-Siguero JP, García-Garcia E, Carralero I, Martínez-Aedo MJ. Adult height in children with idiopathic short stature treated with growth hormone. J Pediatr Endocrinol Metab 2000;13:1595-1602.

76. Coutant R, Rouleau S, Despert F, Magontier N, Loisel D, Limal JM. Growth and adult height in GH-treated children with nonacquired GH deficiency and idiopathic short stature: the influence of pituitary magnetic resonance imaging findings. J Clin Endocrinol Metab $2001 ; 86: 4649-4654$.

77. Wit JM, Rekers-Mombarg LT; Dutch Growth Hormone Advisory Group. Final height gain by GH therapy in children with idiopathic short stature is dose dependent. J Clin Endocrinol Metab 2002;87:604-611.

78. Wit JM, Rekers-Mombarg LT, Cutler GB, Crowe B, Beck TJ, Roberts K, Gill A, Chaussain JL, Frisch H, Yturriaga R, Attanasio AF.Growth hormone (GH) treatment to final height in children with idiopathic short stature: evidence for a dose effect. J Pediatr 2005;146:45-53.

79. van Gool SA, Kamp GA, Odink RJ, de Muinck Keizer-Schrama SM, Delemarre-van de Waal HA, Oostdijk W, Wit JM. High-dose GH treatment limited to the prepubertal period in young children with idiopathic short stature does not increase adult height. Eur J Endocrinol 2010;162:653-660. Epub 2010 Jan 28

80. van Gool SA, Kamp GA, Visser-van Balen H, Mul D, Waelkens JJ, Jansen M, Verhoeven-Wind L, Delemarre-van de Waal HA, de Muinck KeizerSchrama SM, Leusink G, Roos JC, Wit JM. Final height outcome after three years of growth hormone and gonadotropin-releasing hormone agonist treatment in short adolescents with relatively early puberty. J Clin Endocrinol Metab 2007;92:1402-1408. Epub 2007 Feb 6

81. Wickman S, Sipilä I, Ankarberg-Lindgren C, Norjavaara E, Dunkel L. A specific aromatase inhibitor and potential increase in adult height in boys with delayed puberty: a randomised controlled trial. Lancet 2001;357:1743-1748.

82. Cianfarani S. Role of hormones in puberty. Lancet 2001;358:14591460.

83. Hero M, Norjavaara E, Dunkel L.Inhibition of estrogen biosynthesis with a potent aromatase inhibitor increases predicted adult height in boys with idiopathic short stature: a randomized controlled trial. J Clin Endocrinol Metab 2005;90:6396-6402. Epub 2005 Sep 27

84. Mauras N, Ross JL, Gagliardi P, Yu YM, Hossain J, Permuy J, Damaso L, Merinbaum D, Singh RJ, Gaete X, Mericg V. Randomized Trial of Aromatase Inhibitors, Growth Hormone, or Combination in Pubertal Boys with Idiopathic, Short Stature. J Clin Endocrinol Metab 2016;101:4984-4993. Epub 2016 Oct 6
85. Rothenbuhler A, Linglart A, Bougnères P. A randomized pilot trial of growth hormone with anastrozole versus growth hormone alone, starting at the very end of puberty in adolescents with idiopathic short stature. Int J Pediatr Endocrinol 2015;2015:4. Epub 2015 Feb 16

86. Dunkel L. Update on the role of aromatase inhibitors in growth disorders. Horm Res 2009;71 (Suppl 1):57-63. Epub 2009 Jan 21

87. Ranke MB, Lindberg A, Price DA, Darendeliler F, Albertsson-Wikland K, Wilton P, Reiter EO; KIGS International Board. Age at growth hormone therapy start and first-year responsiveness to growth hormone are major determinants of height outcome in idiopathic short stature. Horm Res 2007;68:53-62. Epub 2007 Jan 16

88. Theunissen NC, Kamp GA, Koopman HM, Zwinderman KA, Vogels T, Wit JM. Quality of life and self-esteem in children treated for idiopathic short stature. J Pediatr 2002;140:507-515.

89. Sandberg DE. Quality of life and self-esteem in children treated for idiopathic short stature. J Pediatr 2003;143:691.

90. Ross JL, Sandberg DE, Rose SR, Leschek EW, Baron J, Chipman JJ, Cassorla FG, Quigley CA, Crowe BJ, Roberts K, Cutler GB Jr. Psychological adaptation in children with idiopathic short stature treated with growth hormone or placebo. J Clin Endocrinol Metab 2004;89:4873-4878.

91. Lem AJ, Jobse I, van der Kaay DC, de Ridder MA, Raat H, HokkenKoelega AC. Health-related quality of life in short children born small for gestational age: effects of growth hormone treatment and postponement of puberty. Horm Res Paediatr 2012;77:170-179. Epub 2012 Mar 21

92. Takahashi R, Ogawa M, Osada H. Quality of Life of SGA Children with Short Stature Receiving GH Treatment in Japan. Pediatr Endocrinol Rev 2017;14(Suppl 1):222-228.

93. Pilpel D, Leiberman E, Zadik Z, Carel CA. Effect of growth hormone treatment on quality of life of short-stature children. Horm Res 1995;44:1-5.

94. Coste J, Pouchot J, Carel JC. Height and health-related quality of life: a nationwide population study. J Clin Endocrinol Metab 2012;97:32313239. Epub 2012 Jun 28

95. Quitmann JH, Bullinger M, Sommer R, Rohenkohl AC, Bernardino Da Silva NM. Associations between Psychological Problems and Quality of Life in Pediatric Short Stature from Patients' and Parents' Perspectives. PLoS One 2016;11:e0153953.

96. Sommer G, Gianinazzi ME, Kuonen R, Bohlius J, l'Allemand D, Hauschild M, Mullis PE, Kuehni CE; Swiss Society for Paediatric Endocrinology and Diabetology (SGPED). Health-Related Quality of Life of Young Adults Treated with Recombinant Human Growth Hormone during Childhood. PLoS One 2015;10:e0140944.

97. Carel JC, Ecosse E, Landier F, Meguellati-Hakkas D, Kaguelidou F, Rey G, Coste J. Long-term mortality after recombinant growth hormone treatment for isolated growth hormone deficiency or childhood short stature: preliminary report of the French SAGhE study. J Clin Endocrinol Metab 2012;97:416-425. Epub 2012 Jan 11

98. Poidvin A, Touzé E, Ecosse E, Landier F, Béjot Y, Giroud M, Rothwell PM, Carel JC, Coste J. Growth hormone treatment for childhood short stature and risk of stroke in early adulthood. Neurology 2014;83:780786. Epub 2014 Aug 13

99. Sävendahl L, Maes M, Albertsson-Wikland K, Borgström B, Carel JC, Henrard S, Speybroeck N, Thomas M, Zandwijken G, Hokken-Koelega A. Long-term mortality and causes of death in isolated GHD, ISS, and SGA patients treated with recombinant growth hormone during childhood in Belgium, The Netherlands, and Sweden: preliminary report of 3 countries participating in the EU SAGhE study. J Clin Endocrinol Metab 2012;97:E213-217. Epub 2012 Jan 11

100. Albertsson-Wikland K, Mårtensson A, Sävendahl L, Niklasson A, Bang P, Dahlgren J, Gustafsson J, Kriström B, Norgren S, Pehrsson NG, Odén 
A. Mortality is not increased in rhGH-treated patients when adjusting for birth characteristics. J Clin Endocrinol Metab 2016101:2149-2159. Epub 2016 Feb 26

101. Swerdlow AJ, Cooke R, Beckers D, Borgström B, Butler G, Carel JC, Cianfarani S, Clayton P, Coste J, Deodati A, Ecosse E, Gausche R, Giacomozzi C, Hokken-Koelega ACS, Khan AJ, Kiess W, Kuehni CE, Mullis PE, Pfaffle R, Sävendahl L, Sommer G, Thomas M, Tidblad A, Tollerfield S, Van Eycken L, Zandwijken GRJ. Cancer risks in patients treated with growth hormone in childhood: the SAGhE European cohort study. J Clin Endocrinol Metab 2017;102:1661-1672.

102. Rosenfeld RG, Cohen P, Robison LL, Bercu BB, Clayton P, Hoffman AR, Radovick S, Saenger P, Savage MO, Wit JM. Long-term surveillance of growth hormone therapy. J Clin Endocrinol Metab 2012;97:68-72. Epub 2011 Dec 15

103. Allen DB, Backeljauw P, Bidlingmaier M, Biller BM, Boguszewski M, Burman P, Butler G, Chihara K, Christiansen J, Cianfarani S, Clayton P, Clemmons D, Cohen P, Darendeliler F, Deal C, Dunger D, Erfurth EM, Fuqua JS, Grimberg A, Haymond M, Higham C, Ho K, Hoffman AR, Hokken-Koelega A, Johannsson G, Juul A, Kopchick J, Lee P, Pollak M, Radovick S, Robison L, Rosenfeld R, Ross RJ, Savendahl L, Saenger P, Toft Sorensen H, Stochholm K, Strasburger C, Swerdlow A, Thorner M. GH safety workshop position paper: a critical appraisal of recombinant human GH therapy in children and adults. Eur J Endocrinol 2016;174:P1-9. Epub 2015 Nov 12 